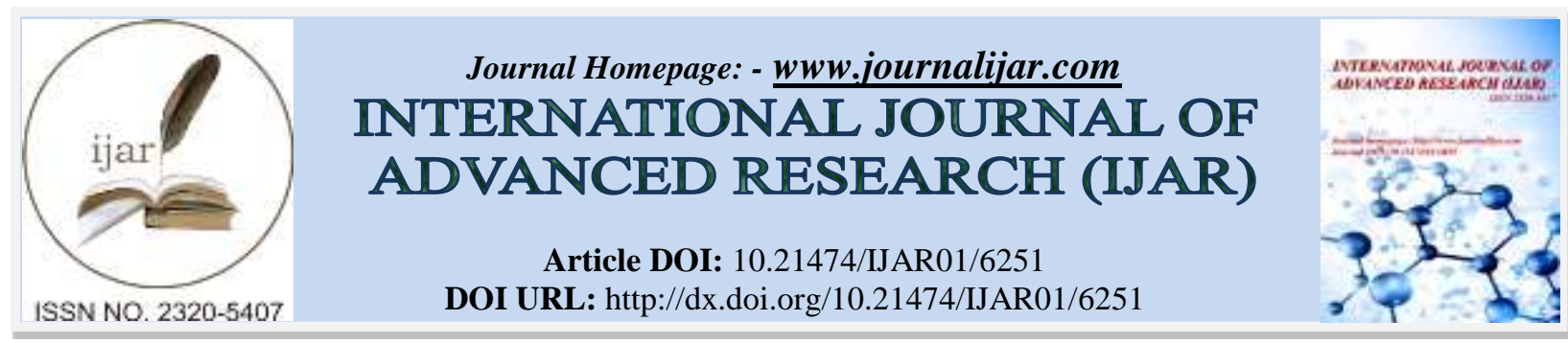

RESEARCH ARTICLE

\title{
ASSOCIATION BETWEEN AMOUNT OF WATER INTAKE AND QUALITY OF SLEEP IN ADULTS - JEDDAH, SAUDI ARABIA.
}

\author{
Mohammad A. Zwawy, Faisal A. Al-Husayni, Samer A. Alamri, Mahmoud F. Qutub, Rakan M. Aljedaani, \\ Abdulaziz A. Al-Zahrani and Khulood A. Al-Siary. \\ King Saud bin Abdulaziz Uiniversity for Health Sciences - Jeddah, Saudi Arabia.
}

\section{Manuscript Info}

Manuscript History

Received: 08 November 2017

Final Accepted: 10 December 2017

Published: January 2018

\section{Abstract}

Copy Right, IJAR, 2018,. All rights reserved.

\section{Introduction:-}

Numerous studies have determined that the bedroom environment as well as lifestyle factors, such as smoking and drinking, can influence sleep. Obesity, hypertension, diabetes and depression, among other diseases, are associated with sleep complaints (1). Sleep has a vital effect on brain functions and many body systems, and neglect of sleep can lead to considerable disadvantages for the individual. Sleep complaints are frequently implicated in problems such as low productivity, risk of accidents and conflict in personal relationships $(2,3)$.

Adequate sleep is required for optimal health (4). Sufficient sleep is linked to mental health, physical activity, and overall quality of life (5-8). In addition, sleep plays an important role in metabolic and emotional regulation, memory consolidation, and learning (9-11). Inadequate sleep has been associated with all-cause mortality, and morbidities (12-17). Epidemiological research suggests that the adequate sleep duration for adults falls between 7 and 8 hours of sleep $(18,19)$. Sleep duration showed a progressive decrease and sleep complaints increased over the last 30 years, hence poor sleep quality has become a widespread problem in modern society $(20,21)$.

A number of serious sleep disorders need to be treated in health care institutions; however, self-management is enough for the majority of cases (22). The bedroom environment and behaviors or activities before bed time are the major controllable risk factors of sleep disorder. Working before going to bed, the use of a mobile phone, noise, lighting, smoking, drinking and caffeine intake have all been implicated in sleep disorders (23-26).

Decreased daily water intake is a problem among the people in countries with hot weather, as is the situation in Saudi Arabia. In Saudi Arabia, several environmental factors, such as hot sunny weather and dry climate, can lead to excessive sweating and subsequently water loss and dehydration. In addition, some diseases may increase water loss e.g. diabetes mellitus, which is relatively common in Saudi population $(27,28)$.

A study on sleep duration in Saudi Arabia found that about one third of Saudi adults do not get enough sleep (sleep less than 7 hours/night) (29). An earlier study showed that people who increased their daily water intake form less than 1.2 liters up to 2-4 liters experienced increased alertness and lesser sleepiness (30). This may lead to decreased 
sleep during the day, which in turn leads to better sleep at night. Hence, the current study was conducted to assess sleep quality and to identify its association with water intake levels in a sample of adults living in Jeddah.

\section{Methods:-}

Study area/setting:

Four different malls located in the East, West, South and North of Jeddah, Saudi Arabia.

Study subjects:

- Inclusion criteria:

Male and female adults living in Jeddah, Saudi Arabia, $1^{\text {st }}$ of December to $31^{\text {st }}$ of December, 2017.

- $\quad$ Exclusion criteria:

- Participants aged less than 18 years old.

- Participants diagnosed with sleep disorders.

- Participants who are using diuretics.

- Participants who are using sleep medications.

Study design:

A cross-sectional study based on a questionnaire survey.

Sample size:

Out of Jeddah city population 3457794 , we recruited 278 participants to be $90 \%$ confident with $5 \%$ margin of error.

Sampling technique:

We used a convenience sampling technique.

Data collection methods, instruments used and measurements:

We designed a brief questionnaire to assess the amount of water intake per day in adults. The questionnaire was pilot-tested by a sample. It was then revised based on reproducibility, validity, and question value. Changes and modifications were made based on the pilot results. The survey was administered during a 1-month period via direct communication to enhance response rates. We used Pittsburgh Sleep Quality Index (PSQI) to assess sleep quality (31).

Data management and analysis plan:

Data analysis was carried out using SPSS version 22. All numerical variables were checked for normality by Shapiro Wilk test. Normally distributed variables were expressed as means \pm standard deviation and differences between groups were tested by Student's unpaired $\mathrm{T}$ test. Abnormally distributed variables were expressed as median and interquartile range (25th - 75th percentile) and mean ranks were calculated for differences testing using Mann-Whitney test. Categorical variables were summarized as frequencies and percentages and association between variables was tested using Pearson's Chi square or Fisher-Freeman-Halton Exact Tests as appropriate. A p-value of $<0.05$ was considered statistically significant.

Ethical considerations:

Ethical approval was taken from IRB of King Abdullah International Medical Research Center before carrying out the study. An informed consent was obtained from each participant before entering the study. The confidentiality of information was strictly maintained.

\section{Results:-}

In this study, 278 participants responded to the questionnaire. Table 1 shows the demographic data and the pattern of water intake of the respondents. The age of respondents ranged from 18 to 70 years with an average $30 \pm 10$ years. Slightly more than half the respondents were males (54.3\%); and nearly one third had a night work (34.9\%). The highest frequency of respondents drink less than $1000 \mathrm{ml}$ per day (31.7\%), followed by those taking 1000-1999 $\mathrm{ml} /$ day (29.9\%), then 2000-2999 (23\%), and the least frequency consumed 3000 or more daily (15.5\%). The majority $(79.9 \%$ ) was used to drink caffeine beverages; among them $49.1 \%$ had one or less cup per day and $42.8 \%$ had 2 to 4 cups daily. The majority did not suffer from chronic diseases $(93.2 \%)$. Half the respondents practiced exercise; among them $70.5 \%$ exercised for 4 hours or less weekly, $25.2 \%$ had exercise for 5 to 10 hours per week, 
and only $4.3 \%$ for more than 10 hours weekly. Figuer 1 shows that only $28.8 \%$ of respondents had adequate sleep duration (7 to 8 hours), while $57.9 \%$ had shortened sleep (less than 7 hours).

Table 2 demonstrates the minimum, maximum, median, and interquartile range for the seven components of PSQI questionnaire and its global score. Figure 2 illustrates that nearly half the respondents (48\%) had PSQI global score 6 or more; indicating poor sleep quality.

Table 3 shows the relationship between global PSQI score and the respondents' demographic data and water consumption pattern. The score was significantly higher in those taking less than $1000 \mathrm{ml} /$ day versus 3000 or more $\mathrm{ml} /$ day (Median 7, 5; mean ranks 161.3, 106.6; $\mathrm{p}<0.003$ ). There were no significant differences in global PSQI as regards different categories of gender $(\mathrm{p}=0.889)$, night work $(\mathrm{p}=0.141)$, caffeine intake $(\mathrm{p}=0.154)$, caffeine cups/day $(p=0.085)$, and hours of exercise/week $(p=0.345)$.

Table 4 illustrates the relationship between water intake and the different components of PSQI score. Decreased water intake was significantly and adversely related to worse subjective sleep quality $(p=0.016)$, habitual sleep deficiency $(\mathrm{p}=0.003)$, sleep disturbance $(\mathrm{p}=0.003)$, and daytime dysfunction $(\mathrm{p}=0.018)$.

\section{Discussion:-}

This study addressed an important issue that was previously understudied; that is the relationship between water intake and the quality of sleep. We found that the highest percentage of adults in Jeddah, Saudi Arabia were used to take less than $1000 \mathrm{ml}$ of water per day (31.7\%), followed by those taking 1000-1999 ml/day (29.9\%), then 20002999 (23\%), and the least percentage consumed 3000 or more daily (15.5\%). This amount is below the daily water needs of adults. An adult needs $2.5 \mathrm{~L}$ if sedentary; and 3.2 L if performing modest physical activity (32-35). More active adults living in a warm environment have daily water needs of about $6 \mathrm{~L}$ (36). Mild dehydration was reported to increase fatigue, decreased activity, and was associated with sleepiness (37-42).

In this study, only $28.8 \%$ of respondents had adequate sleep duration (7 to 8 hours), while $57.9 \%$ had shortened sleep; with average of 7 hours. This average duration of sleep is in agreement to studies in general populations in Britain and students from Palestine, Korea, Iran, Germany, China, and Nigeria that reported an average duration of night sleep $<8$ hours, usually in the range of 6 to 7 hours (43-50). However, the percentage of respondents with shortened sleep duration is much higher than reported in other studies in Saudi Arabia (31 - 33.8\%), and in other studies worldwide $(24.1 \%-41.6 \%)(51-55)$.

Nearly half the respondents (48\%) in this study had poor sleep quality as indicated by global PSQI score. Poor sleep quality has been associated with poor academic achievement and health, as well as increased health care costs and absenteeism from work (56). This prevalence among the adults in Jeddah city is much higher than those reported by other studies (26-35\% using the PSQI) (57-59). However, one of the limitations in our study was the non-inclusion of the respondents' occupations in the study questionnaire; and this may have contributed to this high prevalence of poor sleep quality in our study. A proportion of the respondents may have been university students; and this category is known to suffer from stress due to the burden of studying and examinations (49, 60-62); with a prevalence of poor sleep quality in this population having been reported to range from $19.17 \%$ to 57.5\% (63, 64). Despite the high prevalence of bad sleep quality among the respondents in our study, chronic diseases were reported in a small percentage only. Mental and physical disorders were associated with poor sleep quality (58).

In the present study, the PSQI score showed a tendency to decrease with the increased intake of water; with a significantly higher score in those taking less than $1000 \mathrm{ml} /$ day versus $3000 \mathrm{or} \mathrm{more} \mathrm{ml} /$ day. Decreased water intake was significantly and adversely related to worse subjective sleep quality, habitual sleep deficiency, sleep disturbance, and daytime dysfunction. Increased water intake may result in decreased sleep during the day; which in turn lead to better sleep at night. This finding is supported by previous studies that showed a positive effect of water consumption on alertness $(42,65,66)$.

As sleep quality is likely to be affected by other factors, we evaluated the effect of gender, night work, caffeine beverages, and exercise on the PSQI global score. We found that the majority of respondents were used to drink caffeine containing drinks; about half of them had one or less cup/day and $42.8 \%$ had 2 to 4 cups daily. Caffeine is a methylxanthine that acts as a mild CNS stimulant. It exerts its central effects mainly by inhibiting adenosine, resulting in increased alertness (67-69). Caffeine administration is usually achieved by drinking beverages such as 
tea, coffee, and energy drinks. The caffeine content varies among the different beverages, according to plant source and method of preparation (70). In this study, there were no significant differences in global PSQI as regards caffeine intake or the number of caffeine cups/day. This result agrees with Engleman et al. who found that regular caffeine intake during the day, with the last dose before bedtime by adequate period, did not significantly affect sleep (71). On the other hand, some studies reported that caffeinated coffee increases sleep onset latency, decreases total sleep time and adversely affects sleep quality $(62,72-76)$. However, most of these studies have evaluated the effects of caffeine that has been consumed just before bedtime; which does not resemble the actual, everyday pattern of caffeine consumption (77). Moreover, habitual intake of caffeine ,as is the case in a considerable proportion of Saudi adults, is reported to result in tolerance to caffeine effects (78). Hindmarch et al. found some indication that those individuals whose sleep was most disrupted had the lowest habitual caffeine consumption levels; and concluded that infrequent use of caffeine was likely to enhance sensitivity to caffeine effects (75).

In this study, half the respondents practiced exercise; among them $70.5 \%$ exercised for 4 hours or less weekly, $25.2 \%$ had exercise for 5 to 10 hours per week, and only $4.3 \%$ for more than 10 hours weekly. The sleep quality was not significantly affected by the hours of exercise weekly, a finding that was reported also by other studies (79-82). The absence of significant relationship between sleep quality and hours of exercise/week may be due to the low level of exercise practice among Saudis which was elicited in this study as well as previous studies (83). Other studies have shown that active adolescents were more likely to get high sleep duration compared with inactive peers $(7,84-87)$.

In this study, there was no effect of gender on sleep quality. This contradicts previous studies that showed poorer quality of sleep of females in university and young adults (62, 88-92). Other studies in Saudi Arabia showed either no effect of gender or higher risk of poor sleep in males (93). This difference between the results conducted in Saudi Arabia and other countries is probably due to the conservative nature of Saudi society where females are not allowed to stay late outside home.

\section{Conclusion:-}

It appears that the quality of sleep improves with increased water intake per day. The quality of sleep was not significantly affected by gender, night work, caffeine intake and amount, and hours of exercise per week. The general public should be educated about the benefits of adequate water intake daily, particularly those who suffer from sleep disturbances.

\section{Strengths:-}

This study possessed many points of strengths. We used the PSQI tool to decrease the subjectivity in rating of sleep quality. The sample size was adequate and explored the adult population, which was not studied previously, particularly in Saudi Arabia.

\section{Limitations:-}

This study was subject to some limitations. There was difficulty in specifying the type of caffeinated beverage and the usual times of their intake during the day. Different types of beverages have variable content of caffeine and each type can affect the quality of sleep differently. The effects of some lifestyle factors that affect the quality of sleep - such as the occupation of the respondents, cigarette smoking, heavy drinking, and excessive Internet usage were not investigated, which may throw light on the causes of high prevalence of poor sleep quality.

\section{Acknowledgment:-}

We would like to thank Mapi Research Trust for their support by providing the Pittsburgh Sleep Quality Index.

Table 1:- Demographic data of respondents and water intake (total $\mathrm{N}=278$ ).

\begin{tabular}{|l|l|l|l|}
\hline \multicolumn{2}{|c|}{ Age (years) } & \multicolumn{1}{l|}{$18-70$} \\
\hline \multirow{2}{*}{ Gender } & Mean \pm SD & $30 \pm 10$ & $54.3 \%$ \\
& Male & 151 & $45.7 \%$ \\
\cline { 2 - 4 } & Female & 127 & $65.1 \%$ \\
\hline \multirow{2}{*}{ Night work } & No & 181 & $34.9 \%$ \\
\cline { 2 - 4 } & Yes & 97 & $31.7 \%$ \\
\hline \multirow{2}{*}{ Water per day (ml) } & $<1000$ & 88 & $29.9 \%$ \\
\cline { 2 - 5 } & $1000-1999$ & 83 & \\
\hline
\end{tabular}




\begin{tabular}{|c|c|c|c|c|}
\hline & \multicolumn{2}{|l|}{$2000-2999$} & 64 & $23.0 \%$ \\
\hline & \multicolumn{2}{|l|}{$\geq 3000$} & 43 & $15.5 \%$ \\
\hline \multirow{5}{*}{$\begin{array}{l}\text { Caffeine intake (e.g. tea, coffee, energy } \\
\text { drinks) }\end{array}$} & \multicolumn{2}{|l|}{ No } & 56 & $20.1 \%$ \\
\hline & \multicolumn{2}{|l|}{ Yes } & 222 & $79.9 \%$ \\
\hline & \multirow{3}{*}{$\begin{array}{l}\text { Caffeine } \\
\text { Cups/day }\end{array}$} & $\leq 1$ & 109 & $49.1 \%$ \\
\hline & & $2-4$ & 95 & $42.8 \%$ \\
\hline & & $\geq 5$ & 18 & $8.1 \%$ \\
\hline \multirow[t]{11}{*}{ Chronic diseases } & \multicolumn{2}{|l|}{ None } & 259 & $93.2 \%$ \\
\hline & \multicolumn{2}{|l|}{ Allergic rhinitis } & 1 & $0.4 \%$ \\
\hline & \multicolumn{2}{|l|}{ Anemia } & 1 & $0.4 \%$ \\
\hline & \multicolumn{2}{|l|}{ Asthma } & 2 & $0.8 \%$ \\
\hline & \multicolumn{2}{|l|}{ Diabetes mellitus } & 3 & $1.2 \%$ \\
\hline & \multicolumn{2}{|l|}{ Hypertension } & 1 & $0.4 \%$ \\
\hline & \multicolumn{2}{|l|}{ Dyslipidemia } & 1 & $0.4 \%$ \\
\hline & \multicolumn{2}{|l|}{ Gout } & 1 & $0.4 \%$ \\
\hline & \multicolumn{2}{|l|}{ Hypothyroidism } & 4 & $1.6 \%$ \\
\hline & \multicolumn{2}{|l|}{ IBS } & 1 & $0.4 \%$ \\
\hline & \multicolumn{2}{|l|}{ Sinusitis } & 2 & $0.8 \%$ \\
\hline \multirow[t]{4}{*}{ Exercise per week (hours) } & \multicolumn{2}{|l|}{ None } & 139 & $50.0 \%$ \\
\hline & \multicolumn{2}{|l|}{ Yes } & $\begin{array}{l}139 \\
98\end{array}$ & $\begin{array}{l}50.0 \% \\
70.5 \%\end{array}$ \\
\hline & \multicolumn{2}{|l|}{$5-10$} & 35 & $25.2 \%$ \\
\hline & \multicolumn{2}{|l|}{$>10$} & 6 & $4.3 \%$ \\
\hline
\end{tabular}

SD: standard deviation; IBS: irritable bowel syndrome.

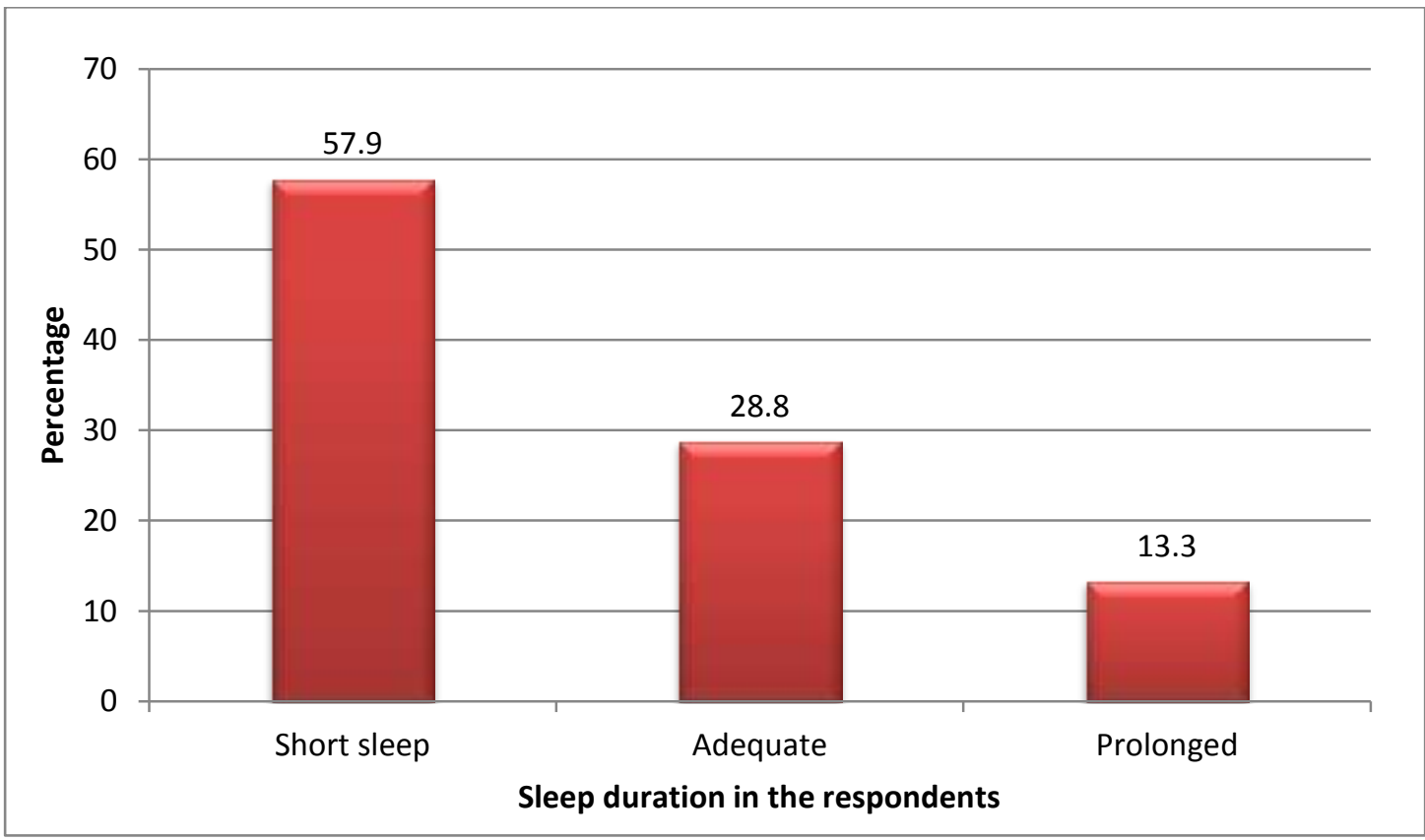

Figure 1:- Sleep duration in the respondents. Adequate duration is 7 to 8 hours, shortened sleep is $<7$ hours, and prolonged sleep $>8$ hours.

Table 2:- Components and global score of Pittsburgh Sleep Quality Index (PSQI).

\begin{tabular}{|l|c|c|c|c|}
\hline & Minimum & Maximum & Median & IQR \\
\hline Component 1 subjective sleep quality & 0 & 3 & 1 & $0-1$ \\
\hline Component 2 sleep latency & 0 & 3 & 1 & $0-2$ \\
\hline Component 3 sleep duration & 0 & 3 & 1 & $0-2$ \\
\hline Component 4 habitual sleep deficiency & 0 & 3 & 0 & $0-1$ \\
\hline Component 5 sleep disturbance & 1 & 3 & 2 & $2-2$ \\
\hline Component 6 use of sleep medications & 0 & 0 & 0 & $0-0$ \\
\hline
\end{tabular}




\begin{tabular}{|l|c|c|c|c|}
\hline Component 7 daytime dysfunction & 0 & 3 & 1 & $0-2$ \\
\hline Global PSQI score & 1 & 17 & 6 & $5-9$ \\
\hline
\end{tabular}

IQR: interquartile range

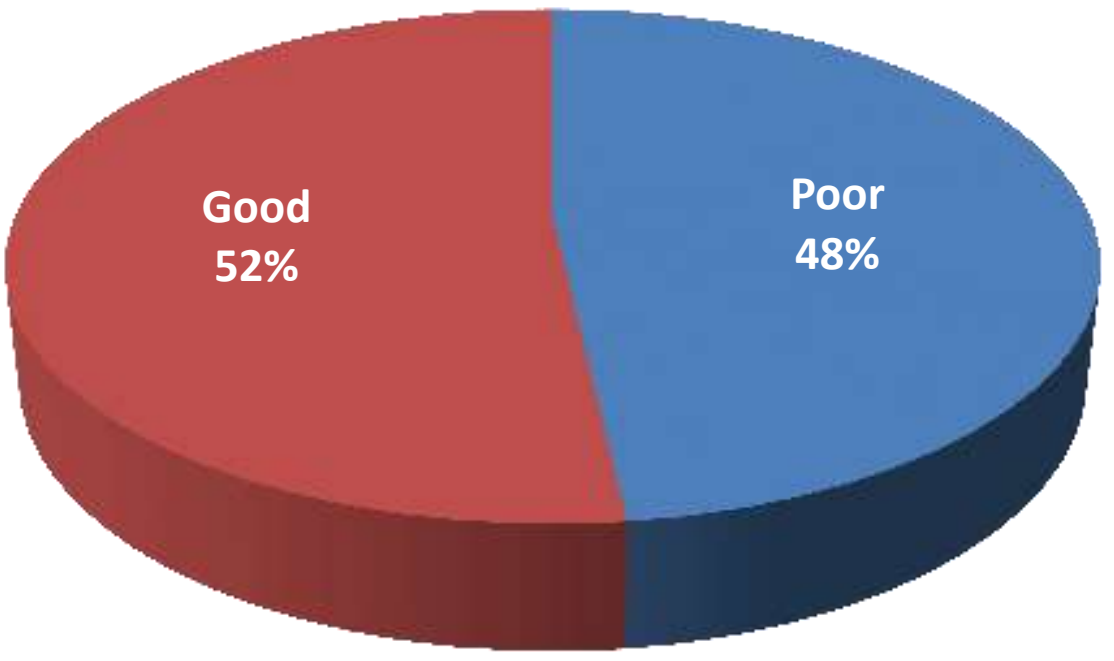

Figure 2:- Sleep quality of the respondents according to PSQI score (poor sleep quality $\leq 6$ ).

Table 3:- Relationship of global PSQI score and demographic and water consumption pattern.

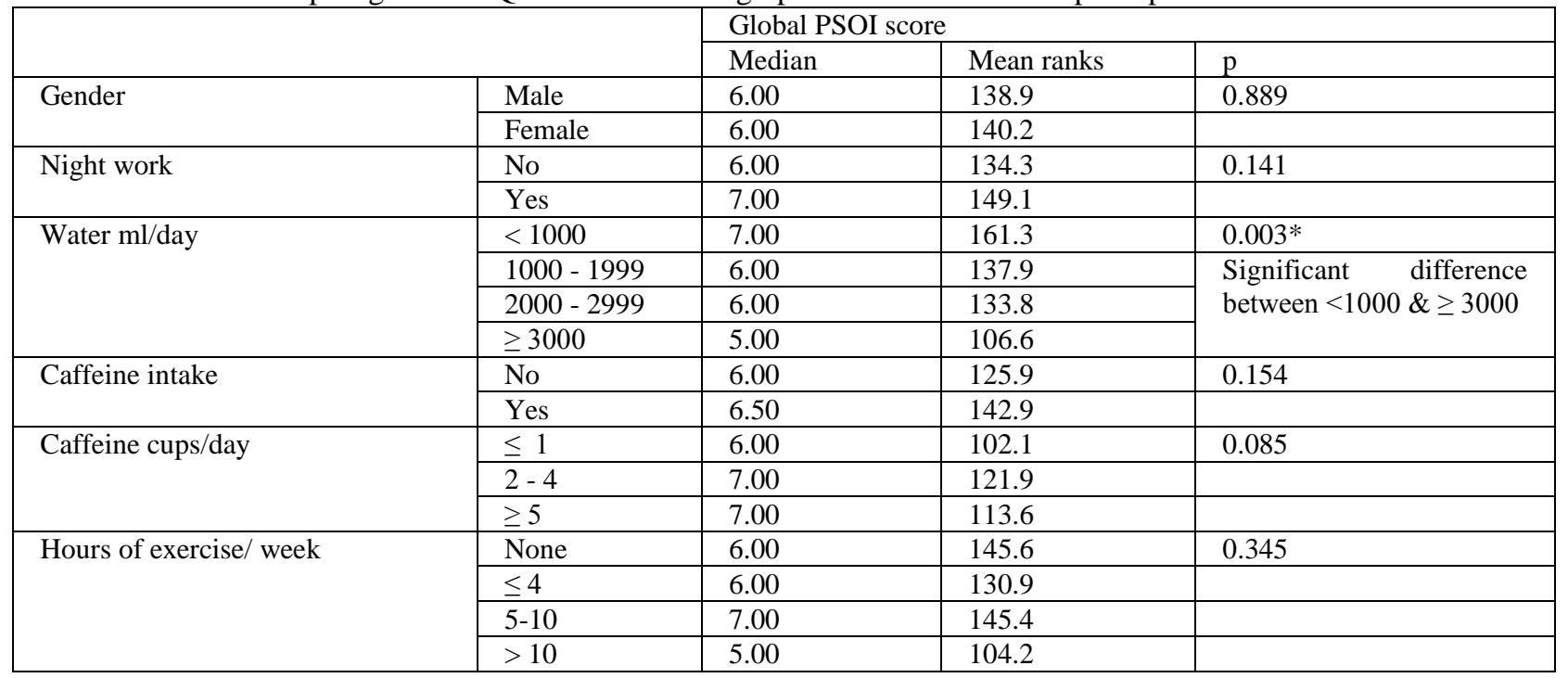

*significant at $\mathrm{p}<0.05$.

Table 4:- Effect of water intake on components of Pittsburgh Sleep Quality Index score.

\begin{tabular}{|c|c|c|c|c|c|c|c|c|c|}
\hline & \multicolumn{8}{|c|}{ Water intake (ml/day) } & \multirow[t]{3}{*}{$\mathrm{p}$} \\
\hline & \multicolumn{2}{|c|}{$<1000$} & \multicolumn{2}{|c|}{$1000-1999$} & \multicolumn{2}{|c|}{$2000-2999$} & \multicolumn{2}{|l|}{$\geq 3000$} & \\
\hline & Median & $\begin{array}{l}\text { Mean } \\
\text { ranks }\end{array}$ & Median & $\begin{array}{l}\text { Mean } \\
\text { ranks }\end{array}$ & Median & $\begin{array}{l}\text { Mean } \\
\text { ranks }\end{array}$ & Median & $\begin{array}{l}\text { Mean } \\
\text { ranks }\end{array}$ & \\
\hline $\begin{array}{l}\text { Component } 1 \text { Subjective } \\
\text { sleep quality }\end{array}$ & 1 & 157.0 & 1 & 133.2 & 1 & 140.3 & 1 & 114.7 & $0.016^{* \mathrm{a}}$ \\
\hline Component 2 Sleep & 1 & 137.5 & 1 & 137.4 & 1 & 154.5 & 1 & 128.4 & 0.259 \\
\hline
\end{tabular}




\begin{tabular}{|c|c|c|c|c|c|c|c|c|c|}
\hline latency & & & & & & & & & \\
\hline $\begin{array}{lll}\begin{array}{l}\text { Component } \\
\text { duration }\end{array} & 3 & \text { Sleep } \\
\end{array}$ & 1 & 145.7 & 1 & 139.3 & 1 & 129.8 & 1 & 141.5 & 0.652 \\
\hline $\begin{array}{l}\text { Component } 4 \text { Habitual } \\
\text { sleep deficiency }\end{array}$ & 0 & 150.3 & 0 & 143.5 & 0 & 137.1 & 0 & 113.2 & $0.020 *^{\mathrm{a}}$ \\
\hline $\begin{array}{lcr}\begin{array}{l}\text { Component } \\
\text { disturbance }\end{array} & 5 & \text { Sleep } \\
\end{array}$ & 2 & 159.8 & 2 & 131.1 & 2 & 134.5 & 2 & 121.7 & $\begin{array}{l}0.003 * \\
\mathrm{ab}\end{array}$ \\
\hline $\begin{array}{l}\text { Component } 6 \text { Use of } \\
\text { sleep medications }\end{array}$ & 0 & 139.5 & 0 & 139.5 & 0 & 139.5 & 0 & 139.5 & 1.000 \\
\hline $\begin{array}{lll}\begin{array}{l}\text { Component } \\
\text { dysfunction }\end{array} & \text { Daytime } \\
\end{array}$ & 1 & 154.3 & 1 & 145.6 & 1 & 128.4 & 1 & 114.1 & $\begin{array}{l}0.018 * \\
\mathrm{a}\end{array}$ \\
\hline
\end{tabular}

*significant at p <0.05; a: significant differences between $<1000 \& \geq 3000$; b: significant differences between $<1000$ \& $1000-1999$.

\section{References:-}

1. Magnavita N, Garbarino S. Sleep, Health and Wellness at Work: A Scoping Review. International journal of environmental research and public health. 2017;14(11).

2. Salminen S, Oksanen T, Vahtera J, Sallinen M, Harma M, Salo P, et al. Sleep disturbances as a predictor of occupational injuries among public sector workers. Journal of sleep research. 2010;19(1 Pt 2):207-13.

3. Sarsour K, Kalsekar A, Swindle R, Foley K, Walsh JK. The association between insomnia severity and healthcare and productivity costs in a health plan sample. Sleep. 2011;34(4):443-50.

4. Bixler E. Sleep and society: an epidemiological perspective. Sleep medicine. 2009;10 Suppl 1:S3-6.

5. Reid KJ, Martinovich Z, Finkel S, Statsinger J, Golden R, Harter K, et al. Sleep: a marker of physical and mental health in the elderly. The American journal of geriatric psychiatry. 2006;14(10):860-6.

6. Shanahan L, Copeland WE, Angold A, Bondy CL, Costello EJ. Sleep problems predict and are predicted by generalized anxiety/depression and oppositional defiant disorder. Journal of the American Academy of Child \& Adolescent Psychiatry. 2014;53(5):550-8.

7. Foti KE, Eaton DK, Lowry R, McKnight-Ely LR. Sufficient sleep, physical activity, and sedentary behaviors. American Journal of Preventive Medicine. 2011;41:596-602.

8. Zammit GK, Weiner J, Damato N, Sillup GP, McMillan CA. Quality of life in people with insomnia. Sleep: Journal of Sleep Research \& Sleep Medicine. 1999.

9. Yoo S-S, Gujar N, Hu P, Jolesz FA, Walker MP. The human emotional brain without sleep-a prefrontal amygdala disconnect. Current Biology. 2007;17(20):R877-R8.

10. Siegel JM. The REM sleep-memory consolidation hypothesis. Science. 2001;294(5544):1058-63.

11. Curcio G, Ferrara M, De Gennaro L. Sleep loss, learning capacity and academic performance. Sleep medicine reviews. 2006;10(5):323-37.

12. Patel SR, Ayas NT, Malhotra MR, White DP, Schernhammer ES, Speizer FE, et al. A prospective study of sleep duration and mortality risk in women. Sleep. 2004;27(3):440-4.

13. Meier-Ewert HK, Ridker PM, Rifai N, Regan MM, Price NJ, Dinges DF, et al. Effect of sleep loss on Creactive protein, an inflammatory marker of cardiovascular risk. Journal of the American College of Cardiology. 2004;43(4):678-83.

14. Gottlieb DJ, Redline S, Nieto FJ, Baldwin CM, Newman AB, Resnick HE, et al. Association of usual sleep duration with hypertension: the Sleep Heart Health Study. Sleep. 2006;29(8):1009-14.

15. Gangwisch JE, Heymsfield SB, Boden-Albala B, Buijs RM, Kreier F, Pickering TG, et al. Sleep duration as a risk factor for diabetes incidence in a large US sample. Sleep. 2007;30(12):1667-73.

16. Cappuccio FP, Taggart FM, Kandala N-B, Currie A, Peile E, Stranges S, et al. Meta-analysis of short sleep duration and obesity in children and adults. Sleep. 2008;31(5):619-26.

17. Sabanayagam C, Shankar A. Sleep duration and cardiovascular disease: results from the National Health Interview Survey. Sleep. 2010;33(8):1037-42.

18. Bixler E. Sleep and society: an epidemiological perspective. Journal of Sleep Medicine. 2009;10:S3-S6.

19. Watson N, Badr M, Belenky G, Bliwise D, Buxton O, Buysse D. Consensus Conference Panel (2015) Joint consensus statement of the American Academy of Sleep Medicine and Sleep Research Society on the recommended amount of sleep for a healthy adult: Methodology and discussion. J Clin Sleep Med.11:931-52.

20. Kronholm E, Partonen T, Laatikainen T, Peltonen M, Harma M, Hublin C, et al. Trends in self-reported sleep duration and insomnia-related symptoms in Finland from 1972 to 2005: a comparative review and re-analysis of Finnish population samples. Journal of Sleep Research. 2008;17:54-62. 
21. Megdal SP, Schernhammer ES. Correlates for poor sleepers in a Los Angeles high school. Sleep medicine. 2007;9(1):60-3.

22. Matsumoto Y, Uchimura N, Ishida T, Morimatsu Y, Mori M, Inoue M, et al. The relationship of sleep complaints risk factors with sleep phase, quality, and quantity in Japanese workers. Sleep and biological rhythms. 2017;15(4):291-7.

23. Munezawa T, Kaneita Y, Osaki Y, Kanda H, Minowa M, Suzuki K, et al. The association between use of mobile phones after lights out and sleep disturbances among Japanese adolescents: a nationwide cross-sectional survey. Sleep. 2011;34(8):1013-20.

24. Muzet A. Environmental noise, sleep and health. Sleep medicine reviews. 2007;11(2):135-42.

25. Van Reen E, Roane BM, Barker DH, McGeary JE, Borsari B, Carskadon MA. Current Alcohol Use is Associated with Sleep Patterns in First-Year College Students. Sleep. 2016;39(6):1321-6.

26. Zhang L, Samet J, Caffo B, Punjabi NM. Cigarette smoking and nocturnal sleep architecture. American journal of epidemiology. 2006;164(6):529-37.

27. Alhazmi RS, Ahmed AAB, Alshalan MH, Alfuhigi ZD, Alhazmi SF, Aldughmi AN, et al. Prevalence of diabetes mellitus and its relation with obesity in Turaif (Saudi Arabia) in 2017. Electronic physician. 2017;9(10):5531-5.

28. Alotaibi A, Perry L, Gholizadeh L, Al-Ganmi A. Incidence and prevalence rates of diabetes mellitus in Saudi Arabia: An overview. Journal of epidemiology and global health. 2017;7(4):211-8.

29. Ahmed AE, Al-Jahdali F, Al AA, Abuabat F, Bin Salih SA, Al-Harbi A, et al. Prevalence of sleep duration among Saudi adults. Saudi medical journal. 2017;38(3):276-83.

30. Pross N, Demazieres A, Girard N, Barnouin R, Metzger D, Klein A, et al. Effects of changes in water intake on mood of high and low drinkers. PloS one. 2014;9(4):e94754.

31. PSQI developed by Buysse,D.J., Reynolds,C.F., Monk,T.H., Berman,S.R., and Kupfer,D.J. of the University of Pittsburgh using National Institute of Mental Health Funding. Buysse DJ, Reynolds CF, Monk TH, Berman SR, Kupfer DJ: Psychiatry Research, 28:193-213, 1989.

32. Miller ME, Cosgriff J, Forbes GB. Bromide space determination using anion-exchange chromatography for measurement of bromide. The American journal of clinical nutrition. 1989;50(1):168-71.

33. Gudivaka R, Schoeller D, Kushner RF. Effect of skin temperature on multifrequency bioelectrical impedance analysis. Journal of Applied Physiology. 1996;81(2):838-45.

34. Vaisman N, Pencharz PB, Koren G, Johnson JK. Comparison of oral and intravenous administration of sodium bromide for extracellular water measurements. The American journal of clinical nutrition. 1987;46(1):1-4.

35. Maw GJ, MacKenzie IL, Comer D, Taylor N. Whole-body hyperhydration in endurance-trained males determined using radionuclide dilution. Medicine and science in sports and exercise. 1996;28(8):1038-44.

36. Fairbanks VF, Klee GG, Wiseman GA, Hoyer JD, Tefferi A, Petitt RM, et al. Measurement of blood volume and red cell mass: re-examination of $51 \mathrm{Cr}$ and $125 \mathrm{I}$ methods. Blood Cells, Molecules, and Diseases. 1996;22(2):169-86.

37. Shirreffs SM, Merson SJ, Fraser SM, Archer DT. The effects of fluid restriction on hydration status and subjective feelings in man. British Journal of Nutrition. 2004;91(6):951-8.

38. Szinnai G, Schachinger H, Arnaud MJ, Linder L, Keller U. Effect of water deprivation on cognitive-motor performance in healthy men and women. American Journal of Physiology-Regulatory, Integrative and Comparative Physiology. 2005;289(1):R275-R80.

39. Petri NM, Dropulić N, Kardum G. Effects of voluntary fluid intake deprivation on mental and psychomotor performance. Croatian medical journal. 2006;47(6):0-861.

40. Ganio MS, Armstrong LE, Casa DJ, McDermott BP, Lee EC, Yamamoto LM, et al. Mild dehydration impairs cognitive performance and mood of men. British Journal of Nutrition. 2011;106(10):1535-43.

41. Armstrong LE, Ganio MS, Casa DJ, Lee EC, McDermott BP, Klau JF, et al. Mild Dehydration Affects Mood in Healthy Young Women, 2. The Journal of nutrition. 2011;142(2):382-8.

42. Pross N, Demazières A, Girard N, Barnouin R, Metzger D, Klein A, et al. Effects of changes in water intake on mood of high and low drinkers. PLoS One. 2014;9(4):e94754.

43. Groeger JA, Zijlstra FR, Dijk DJ. Sleep quantity, sleep difficulties and their perceived consequences in a representative sample of some 2000 British adults. J Sleep Res. 2004;13.

44. Sweileh WM, Ali IA, Sawalha AF, Abu-Taha AS, Zyoud SeH, Al-Jabi SW. Sleep habits and sleep problems among Palestinian students. Child and Adolescent Psychiatry and Mental Health. 2011;5(1):25.

45. Ban DJ, Lee TJ. Sleep duration, subjective sleep disturbances and associated factors among university students in Korea. J Korean Med Sci. 2001;16. 
46. Joo S, Shin C, Kim J. Prevalence and correlates of excessive daytime sleepiness in high school students in Korea. Psychiatry Clin Neurosci. 2005;59.

47. Ghanizadeh A, Kianpoor M, Rezaei M. Sleep patterns and habits in high school students in Iran. Annals of General Psychiatry. 2008;7:5.

48. Loessl G, Valerius G, Kopasz M, Hornyak M, Riemann D, Voderholzer U. Are adolescents chronically sleepdeprived? An investigation of sleep habits of adolescents in the Southwest of Germany. Child Care Health Dev. 2008;34.

49. Tsui Y, Wing Y. A study on the sleep patterns and problems of university business students in Hong Kong. Journal of American college health. 2009;58(2):167-76.

50. Oluwole OS. Sleep habits in Nigerian undergraduates. Acta Neurol Scand. 2010;121.

51. Al-Hazzaa HM, Musaiger AO, Abahussain NA, Al-Sobayel HI, Qahwaji DM. Prevalence of short sleep duration and its association with obesity among adolescents 15-to 19-year olds: A cross-sectional study from three major cities in Saudi Arabia. Annals of thoracic medicine. 2012;7(3):133.

52. Ahmed AE, Al-Jahdali F, AlALwan A, Abuabat F, Salih SB, Al-Harbi A, et al. Prevalence of sleep duration among Saudi adults. Saudi medical journal. 2017;38(3):276.

53. Resnick HE, Redline S, Shahar E, Gilpin A, Newman A, Walter R, et al. Diabetes and sleep disturbances. Diabetes care. 2003;26(3):702-9.

54. Tuomilehto H, Peltonen M, Partinen M, Seppä J, Saaristo T, Korpi-Hyövälti E, et al. Sleep duration is associated with an increased risk for the prevalence of type 2 diabetes in middle-aged women-The FIN-D2D survey. Sleep medicine. 2008;9(3):221-7.

55. Liu Y. Prevalence of healthy sleep duration among adults-United States, 2014. MMWR Morbidity and mortality weekly report. 2016;65.

56. Trockel MT, Barnes MD, Egget DL. Health-related variables and academic performance among first-year college students: implications for sleep and other behaviors. Journal of American college health. 2000;49(3):125-31.

57. Chung KF, Tang MK. Subjective sleep disturbance and its correlates in middle-aged Hong Kong Chinese women. Maturitas. 2006;53(4):396-404.

58. Stein MB, Belik S-L, Jacobi F, Sareen J. Impairment associated with sleep problems in the community: relationship to physical and mental health comorbidity. Psychosomatic Medicine. 2008;70(8):913-9.

59. Yao K-W, Yu S, Cheng S-P, Chen I-J. Relationships between personal, depression and social network factors and sleep quality in community-dwelling older adults. Journal of Nursing Research. 2008;16(2):131-9.

60. Yang C-M, Wu C-H, Hsieh M-H, Liu M-H, Lu F-H. Coping with sleep disturbances among young adults: a survey of first-year college students in Taiwan. Behavioral medicine. 2003;29(3):133-8.

61. Suen LK, Ellis Hon K, Tam WW. Association between Sleep Behavior and Sleep-Related Factors among University Students in Hong Kong. Chronobiology international. 2008;25(5):760-75.

62. Cheng SH, Shih C-C, Lee IH, Hou Y-W, Chen KC, Chen K-T, et al. A study on the sleep quality of incoming university students. Psychiatry research. 2012;197(3):270-4.

63. Feng G, Chen J, Yang X. Study on the status and quality of sleep-related influencing factors in medical college students. Zhonghua liu xing bing xue za zhi= Zhonghua liuxingbingxue zazhi. 2005;26(5):328-31.

64. Suen LK, Hon KL, Tam WW. Association between sleep behavior and sleep related factors among university students in Hong Kong. Chronobiology International. 2008;25:760-75.

65. Rogers PJ, Kainth A, Smit H. A drink of water can improve or impair mental performance depending on small differences in thirst. Appetite. 2001;36(1):57-8.

66. Neave N, Scholey A, Emmett J, Moss M, Kennedy D, Wesnes K. Water ingestion improves subjective alertness, but has no effect on cognitive performance in dehydrated healthy young volunteers. Appetite. 2001;37(3):255-6.

67. Bruce M, Lader M. Caffeine: Clinical and experimental effects in humans. Human Psychopharmacology: Clinical and Experimental. 1986;1(2):63-82.

68. Wurzner H. Action du café sur les performances humaines. Café, Cacao, Thé (Francia) v 32 (1) p 49-56. 1988.

69. Deckert J, Gleiter $\mathrm{CH}$. Adenosinergic psychopharmaceuticals: just an extra cup of coffee? Journal of Psychopharmacology. 1990;4(4):183-7.

70. Barone JJ, Roberts HR. Caffeine consumption. Food Chem Toxicol. 1996;34:119-29.

71. Engleman H, Ronald P, Shapiro C, editors. The effect of caffeine and sleep deprivation on daytime performance. Xth European Congress on Sleep Research, Strasbourg, France; 1990.

72. Smith JM, Misiak H. Critical flicker frequency (CFF) and psychotropic drugs in normal human subjects-a review. Psychopharmacology. 1976;47(2):175-82. 
73. Curless R, French J, James O, Wynne H. Is caffeine a factor in subjective insomnia of elderly people? Age and ageing. 1993;22(1):41-5.

74. Penetar D, McCann U, Thorne D, Kamimori G, Galinski C, Sing H, et al. Caffeine reversal of sleep deprivation effects on alertness and mood. Psychopharmacology. 1993;112(2-3):359-65.

75. Hindmarch I, Rigney U, Stanley N, Quinlan P, Rycroft J, Lane J. A naturalistic investigation of the effects of day-long consumption of tea, coffee and water on alertness, sleep onset and sleep quality. Psychopharmacology. 2000;149(3):203-16.

76. Sin CW, Ho JS, Chung JW. Systematic review on the effectiveness of caffeine abstinence on the quality of sleep. Journal of Clinical Nursing. 2009;18(1):13-21.

77. Snel J. Coffee and caffeine: Sleep and wakefulness. Raven Press, New York; 1993.

78. Zwyghuizen-Doorenbos A, Roehrs TA, Lipschutz L, Timms V, Roth T. Effects of caffeine on alertness. Psychopharmacology. 1990;100(1):36-9.

79. Youngstedt SD, Perlis ML, O'Brien PM, Palmer CR, Smith MT, Orff HJ, et al. No association of sleep with total daily physical activity in normal sleepers. Physiology \& behavior. 2003;78(3):395-401.

80. Benefice E, Garnier D, Ndiaye G. Nutritional status, growth and sleep habits among Senegalese adolescent girls. European journal of clinical nutrition. 2004;58(2):292-301.

81. Nixon GM, Thompson JM, Han DY, Becroft DM, Clark PM, Robinson E, et al. Short sleep duration in middle childhood: risk factors and consequences. Sleep. 2008;31(1):71-8.

82. Ortega FB, Ruiz JR, Labayen I, Kwak L, Harro J, Oja L, et al. Sleep duration and activity levels in Estonian and Swedish children and adolescents. European journal of applied physiology. 2011;111(10):2615-23.

83. Al-Hazzaa HM, Al-Ahmadi M. A Self-reported questionnaire for the assessment of physical activity in youth 15-25 years: development, reliability and construct validity. Arab Journal of Food \& Nutrition. 2003;4:279-91.

84. Tanaka H, Taira K, Arakawa M, Masuda A, Yamamoto Y, Komoda Y, et al. An examination of sleep health, lifestyle and mental health in junior high school students. Psychiatry Clin Neurosci. 2002;56(3):235-6.

85. Hitze B, Bosy-Westphal A, Bielfeldt F, Settler U, Plachta-Danielzik S, Pfeuffer M, et al. Determinants and impact of sleep duration in children and adolescents: data of the Kiel Obesity Prevention Study. European journal of clinical nutrition. 2009;63(6):739-46.

86. Brand S, Gerber M, Beck J, Hatzinger M, Pühse U, Holsboer-Trachsler E. High exercise levels are related to favorable sleep patterns and psychological functioning in adolescents: a comparison of athletes and controls. The Journal of Adolescent Health. 2010;46:133-41.

87. McKnight-Eily LR, Eaton DK, Lowry R, Croft JB, Presley-Cantrell L, Perry GS. Relationships between hours of sleep and health-risk behaviors in US adolescent students. Preventive Medicine. 2011;53:271-3.

88. Tsai L-L, Li S-P. Sleep patterns in college students: Gender and grade differences. Journal of psychosomatic research. 2004;56(2):231-7.

89. Lindberg E, Janson C, Gislason T, Björnsson E, Hetta J, Boman G. Sleep disturbances in a young adult population: can gender differences be explained by differences in psychological status? Sleep. 1997;20(6):3817.

90. Ohida T, Osaki Y, Doi Y, Tanihata T, Minowa M, Suzuki K, et al. An epidemiologic study of self-reported sleep problems among Japanese adolescents. Sleep. 2004;27(5):978-85.

91. Fischer FM, Nagai R, Teixeira LR. Explaining Sleep Duration in Adolescents: The Impact of SocioDemographic and Lifestyle Factors and Working Status. Chronobiology international. 2008;25(2-3):359-72.

92. Xiang Y-T, Ma X, Cai Z-J, Li S-R, Xiang Y-Q, Guo H-L, et al. The prevalence of insomnia, its sociodemographic and clinical correlates, and treatment in rural and urban regions of Beijing, China: a general population-based survey. Sleep. 2008;31(12):1655-62.

93. Al-Hazzaa HM, Musaiger AO, Abahussain NA, Al-Sobayel HI, Qahwaji DM. Lifestyle correlates of selfreported sleep duration among Saudi adolescents: a multicentre school-based cross-sectional study. Child Care Health Dev. 2014;40(4):533-42. 